\title{
Improvement of nutritional quality of ruminant feed composed of soybean straw and ryegrass hay
}

Melhoria da qualidade nutricional da ração de ruminantes composta por palha de soja e feno de azevém

\author{
C. K. Zen; K. B. Sartor; R. V. da Silva; L. M. Colla; C. O. Reinehr* \\ Programa de Pós-Graduação em Ciência e Tecnologia de Alimentos, Universidade de Passo Fundo, Campus I,
} 99052-900, Passo Fundo, RS, Brasil

*reinehr@upf.br

(Recebido em 13 de agosto de 2020; aceito em 12 de dezembro de 2020)

\begin{abstract}
The purpose of this study was to increase the nutritional value of two raw materials (soybean straw and ryegrass hay), in order to propose the use as feed for ruminants. Different technologies were used to develop the animal feed: addition of proteins, addition of Spirulina platensis biomass, solid state fermentation by Aspergillus niger, encapsulation of microalgae biomass (capsules with xanthan gum and chitosan), as well as the control tests. The chemical composition (moisture, crude protein, lipids, ash, crude fiber, neutral detergent fiber and acid detergent fiber) of the different treatments was determined. Although the solid state fermentation using the fungus Aspergillus niger did not decrease the fiber content, the addition of microalgae biomass in soybean straw and ryegrass hay improved the quality of bulky feed, increasing until $87 \%$ and $80 \%$ protein content of soybean straw and ryegrass hay, respectively. Furthermore, the addition of Spirulina biomass in soy straw, with gelatin or encapsulated, decreased the content of neutral detergent fiber and acid detergent fiber. The bypass protein obtained using the encapsulated biomass allows the use of agro-industrial waste, adding nutritional value to bulky feed, which may increase the milk production by lactating cows.

Keywords: encapsulation, Aspergillus niger, Spirulina platensis
\end{abstract}

O objetivo deste estudo foi aumentar o valor nutricional de duas matérias-primas (palha de soja e feno de azevém), a fim de propor o uso como ração para ruminantes. Diferentes tecnologias foram utilizadas para desenvolver a alimentação animal: adição de proteínas, adição de biomassa de Spirulina platensis, fermentação em estado sólido por Aspergillus niger, encapsulação de biomassa de microalgas (cápsulas de goma xantana e quitosana), bem como os testes de controle. A composição química (umidade, proteína, lipídios, cinzas, fibra bruta, fibra em detergente neutro e fibra em detergente ácido) dos diferentes tratamentos foi determinada. Embora a fermentação em estado sólido com o fungo Aspergillus niger não tenha diminuído o teor de fibras, a adição de biomassa de microalgas na palha de soja e no feno de azevém melhorou a qualidade da ração volumosa, aumentando até $87 \%$ e $80 \%$ o teor de proteínas da palha de soja e do feno de azevém, respectivamente. Além disso, a adição de biomassa de Spirulina na palha de soja, com gelatina ou encapsulada, diminuiu o teor de fibra em detergente neutro e fibra em detergente ácido. A proteína bypass obtida a partir da biomassa encapsulada permite o aproveitamento de resíduos agroindustriais, agregando valor nutricional à ração volumosa, o que pode aumentar a produção de leite por vacas em lactação.

Palavras-chave: encapsulação, Aspergillus niger, Spirulina platensis

\section{INTRODUCTION}

The correct feeding of cattle is an important aspect in obtaining the maximum productive performance. An alternative commonly used in the feeding of ruminants is the ingestion of bulk feed, with more than $18 \%$ crude fiber and low energy, since ruminants have the ability to obtain energy from fibrous foods due to a rich and diverse microbiota in the rumen [1]. This type of animal feed includes residues from agribusiness, ears, straw, silage, hay, among others, which tend to reduce competition between human and animal nutrition [2].

Soybean straw is a low cost abundant and renewable source, composed of stems, barks and dry leaves. After harvesting soybean, large amounts of straw remain on the farm and are not used as cattle feed, mainly because of its low nutritional value [3]. Ryegrass hay is a resource for cattle ranchers to keep productivity during the driest periods or the winter. The chemical composition 
varies according to the conditions of the hay production process, storage, type of forage, cutting time, besides other factors [4], which can reduce the quality of the hay, making it unsuitable for animal feeding.

The use of soybean straw and ryegrass hay for cattle feeding requires the incorporation of compounds that increase its nutritional value, providing nutrients in adequate quantity and quality. An alternative is the incorporation of microbial biomass, which may have high values of proteins and other nutrients. Examples of microorganisms that can be added are filamentous fungi and microalgae [5].

Fungi grow in different industrial byproducts, producing numerous cells and microbial protein that are used in animal feed. Aspergillus niger is a filamentous fungus considered safe for application in foods according to the FDA (Food and Drug Administration). Its use in fermentation has some advantages over other fungi, such as ease of handling, the ability to ferment a wide variety of low-cost raw materials and produce high yields of bioproducts. Solid state fermentation has been widely used in protein enrichment of agro-industrial residues in order to be used in animal feed, in the production of enzymes and different metabolites [6]. The use of lignocellulosic residues as substrates for solid state fermentation increases fiber digestibility and can be consumed by ruminants [7].

Microalgae are being recognized for commercial applications for growing rapidly and for producing compounds of industrial interest [8]. Spirulina platensis is a photosynthetic filamentous cyanobacterium which grows with high levels of carbonate and bicarbonate [9]. Its biomass can be used as human or animal food supplement $[10,11]$, presenting polyunsaturated fatty acids, vitamins and high protein content $[9,12]$.

Ruminants require the provision of two types of digestible protein in their diet: the rumendegradable protein and the protein which escapes ruminal degradation and is digested in the small intestine, that is called bypass protein [13]. The amount of protein that does not suffer ruminal degradation depends on the type of food. A way to reduce the degradation of high quality protein and amino acids is the encapsulation with polymeric compounds, such as xanthan gum and chitosan, controlling clearance of the core material at desired sites.

Encapsulation is the most commonly used process to protect substances from ruminal degradation. The capsules can be formulated to allow controlled release of the core material in desired locations, such as the intestine, improving its effectiveness and action [14]. Encapsulation is a process of packaging particles in edible capsules. The encapsulated material is called the core or filling, and the material that forms the capsule, encapsulant, wall or cover [15], that is, it is a procedure in which a substance is covered by a material that insulates it totally or partially from the environment. Several materials can be encapsulated, such as enzymes, microorganisms, flavoring agents, acidulants, dyes, lipids, vitamins and minerals [16].

This study aimed to evaluate the nutritional enrichment of soybean straw and ryegrass hay for animal feed using different technologies (solid state fermentation by Aspergillus niger, addition of Spirulina platensis biomass and encapsulation).

\section{MATERIALS AND METHODS}

\subsection{Raw materials and microorganisms}

The raw materials (soyben straw and ryegrass hay) used in this study were supplied by a local farmer (Sananduva, RS, Brazil). Spirulina platensis biomass was supplied provided by the Federal University of Rio Grande, with the following chemical composition in dry basis: $71.8 \%$ crude protein, $11.2 \%$ carbohydrates, $2.9 \%$ lipids and $14.1 \%$ ash. The percent of total solids of dry biomass was 90\% [17]. Aspergillus niger, isolated in a previous work [18] was used for solid state fermentation. The chemicals (gelatin, xanthan gum, chitosan) were supplied by Merck (Hamburg, Germany). 


\subsection{Experimental design}

To add nutritional value to the animal feed, several different treatments were prepared with soybean straw (SS) and ryegrass hay (RH): addition of dry biomass of the microalga Spirulina platensis with gelatin (SSGS and RHGS) and respective controls only with gelatin (SSG and RHG), fermentation with Aspergillus niger (SSF and RHF), addition of encapsulated Spirulina platensis (SSMS and RHMS) and respective controls with the empty capsules of xanthan gum and chitosan (SSXC and RHXC).

For the SSGS and RHGS treatments, the dry biomass of the microalga Spirulina platensis was incorporated into the soybean straw and ryegrass hay by preparing a gelatin gel to which the dry biomass was added. The gel was prepared with $100 \mathrm{~mL}$ of water and $2 \mathrm{~g}$ of gelatin. Then, $10 \mathrm{~g}$ of Spirulina biomass was added and mixed in $100 \mathrm{~g}$ of each roughage. The controls were prepared with the same proportion of gelatin, but without Spirulina.

The fungus Aspergillus niger was used to accumulate proteins via solid state fermentation in SSF and RHF treatments. The inoculum preparation was carried out by inoculating the microorganism in 1-L flasks, containing $100 \mathrm{~mL}$ of Potato Dextrose Agar (PDA), followed by incubation at $30^{\circ} \mathrm{C}$ for $7 \mathrm{~d}$. The culture media were prepared with soybean straw and ryegrass hay. In $100 \%$ of each medium, distilled water was added until it reached $60 \%$ moisture. The medium was autoclaved for $20 \mathrm{~min}$ at $121^{\circ} \mathrm{C}$ and added to $600 \mathrm{~mL}$ sterile flasks. The inoculation was carried out by adding a spore suspension with $10^{7}$ spores/g of medium in the initial time. The flasks were incubated at $30^{\circ} \mathrm{C}$ for $7 \mathrm{~d}$. The fermented roughage was dried until $\sim 14 \%$ moisture.

The SSMS and RHMS treatments (and respective controls) were carried out using an encapsulation process. Chitosan and xanthan gum capsules were prepared by adapting the method of Argin-Soysal, Kofinas e Lo (2009) [19]. The 1\% chitosan solution was prepared with $6 \mathrm{~g}$, dissolved in $600 \mathrm{~mL} \mathrm{HCl} 1 \mathrm{~mol} / \mathrm{L}$ with continuous stirring (Turratec model TE-102, Tecnal, Piracicaba, SP, Brazil) for $2 \mathrm{~h}$ and at $50^{\circ} \mathrm{C}$. Subsequently, the solution was filtered and adjusted to $\mathrm{pH} 6.0$ with $40 \% \mathrm{NaOH}$, stirring for $3 \mathrm{~h}$ at $50^{\circ} \mathrm{C}$. The $2 \%$ xanthan gum solution was prepared with $2 \mathrm{~g}$ in $100 \mathrm{ml}$ at $45^{\circ} \mathrm{C}$. Upon reaching room temperature, $15 \mathrm{~g}$ of dry Spirulina platensis biomass were added. The capsules were formed by dropwise adding the xanthan gum gel with Spirulina in the chitosan solution. The chitosan solution was continuously stirred for $3 \mathrm{~h}$ at room temperature to allow the capsules to cross-link and prevent their coalescence. The feed was prepared by incorporating the encapsulated biomass of Spirulina platensis in soybean straw and ryegrass hay. In $100 \mathrm{~g}$ of each roughage, the entire gel was added with the encapsulated microalga. The drying of the feed was carried out at $60^{\circ} \mathrm{C}$ until it reached $\sim 14 \%$ moisture. The controls were prepared by incorporating empty capsules (without Spirulina) to the feed.

\subsection{Chemical analysis}

The chemical composition of the different treatments was determined: moisture, crude protein, lipids and ash according to AOAC (2005) [20], crude fiber according to AOCS (2003) [21], neutral detergent fiber and acid detergent fiber according to Nogueira, Seródio e Agudo (2002) [22]. All tests were carried out in triplicates. The results were submitted to analysis of variance (ANOVA), using Statistica ${ }^{\circledR}$ (version 7, Statsoft) and the means were compared using the Tukey test at $95 \%$ confidence level.

\section{RESULTS}

The results of chemical composition of the treatments are presented in Table 1 and Table 2. The inclusion of the microalga Spirulina platensis and the fermentation with Aspergillus niger affected significantly $(\mathrm{p}<0.05)$ the evaluated parameters.

The results showed that the inclusion of gelatin increased the crude protein in $24 \%$ of the soybean straw and $17 \%$ of the ryegrass hay. Furthermore, the addition of gelatin and Spirulina showed a protein concentration $87 \%$ and $80 \%$ higher than the control treatments, respectively. With regard to fermentation with Aspergillus, this process increased in $19 \%$ the protein content of 
soybean straw but decreased in $35 \%$ the protein content of ryegrass hay. Fermented feed also showed higher content of crude fiber for both raw materials. The ash content was significantly ( $\mathrm{p}$ $<0.05$ ) higher in treatments involving capsules (empty spheres or containing Spirulina) for both raw materials.

Neutral detergent fiber (NDF) was increased in both forages when fermentation was carried out. However, the addition of the microalga Spirulina and gelatin decreased NDF. Acid detergent fiber (ADF) showed a significant $(\mathrm{p}<0.05)$ decrease when capsules with Spirulina were added.

Table 1: Chemical composition (\% dry basis) of soybean straw and ryegrass hay with or without encapsulated Spirulina platensis.

\begin{tabular}{ccccc}
\hline Treatment & Crude protein & Lipids & Ash & Carbohydrates \\
\hline SS & $6.59 \pm 0.14^{\mathrm{e}}$ & $2.07 \pm 0.13^{\mathrm{c}}$ & $6.14 \pm 0.12^{\mathrm{de}}$ & $85.20 \pm 0.03^{\mathrm{ab}}$ \\
SSG & $8.20 \pm 0.05^{\mathrm{c}}$ & $1.18 \pm 0.11^{\mathrm{de}}$ & $6.42 \pm 0.19^{\mathrm{cde}}$ & $84.20 \pm 0.29^{\mathrm{bc}}$ \\
SSGS & $12.30 \pm 0.18^{\mathrm{a}}$ & $2.54 \pm 0.07^{\mathrm{bc}}$ & $6.95 \pm 0.05^{\mathrm{cde}}$ & $78.22 \pm 0.11^{\mathrm{fg}}$ \\
SSF & $7.87 \pm 0.05^{\mathrm{cd}}$ & $3.22 \pm 0.49^{\mathrm{a}}$ & $7.78 \pm 0.17^{\mathrm{c}}$ & $81.13 \pm 0.40^{\mathrm{de}}$ \\
SSXC & $5.88 \pm 0.56^{\mathrm{e}}$ & $1.04 \pm 0.09^{\mathrm{de}}$ & $14.77 \pm 1.06^{\mathrm{a}}$ & $78.31 \pm 1.67^{\mathrm{fg}}$ \\
SSMS & $10.67 \pm 0.05^{\mathrm{b}}$ & $1.46 \pm 0.13^{\mathrm{d}}$ & $14.70 \pm 0.04^{\mathrm{a}}$ & $73.17 \pm 0.15^{\mathrm{h}}$ \\
\hline RH & $6.71 \pm 0.14^{\mathrm{de}}$ & $2.16 \pm 0.03^{\mathrm{c}}$ & $7.19 \pm 0.11^{\mathrm{cd}}$ & $83.94 \pm 0.05^{\mathrm{bc}}$ \\
RHG & $7.84 \pm 0.20^{\mathrm{cd}}$ & $1.16 \pm 0.05^{\mathrm{de}}$ & $6.42 \pm 0.05^{\mathrm{cde}}$ & $84.59 \pm 0.15^{\mathrm{b}}$ \\
RHGS & $12.08 \pm 0.18^{\mathrm{a}}$ & $1.44 \pm 0.06^{\mathrm{d}}$ & $7.05 \pm 0.19^{\mathrm{cde}}$ & $79.42 \pm 0.15^{\mathrm{ef}}$ \\
RHF & $4.39 \pm 1.04^{\mathrm{f}}$ & $2.79 \pm 0.44^{\mathrm{ab}}$ & $5.62 \pm 0.27^{\mathrm{e}}$ & $87.20 \pm 0.96^{\mathrm{a}}$ \\
RHXC & $4.11 \pm 0.67^{\mathrm{f}}$ & $0.71 \pm 0.05^{\mathrm{e}}$ & $12.92 \pm 0.14^{\mathrm{b}}$ & $82.26 \pm 0.60^{\mathrm{cd}}$ \\
RHMS & $10.14 \pm 0.25^{\mathrm{b}}$ & $0.94 \pm 0.07^{\mathrm{de}}$ & $12.60 \pm 1.26^{\mathrm{b}}$ & $76.32 \pm 1.23^{\mathrm{g}}$ \\
\hline
\end{tabular}

NDF: neutral detergent fiber; ADF: acid detergent fiber; SS: Soybean straw; SSG: SS with gelatin; SSGS: SSG with Spirulina platensis; SSF: SS fermented by Aspergillus niger; SSXC: SS with xanthan gum and chitosan; SSMP: SS with encapsulated Spirulina platensis; RH: Ryegrass hay; RHG: RH with gelatin; RHGS: RHG with Spirulina platensis; RHF: RH fermented by Aspergillus niger; RHXC: RH with xanthan gum and chitosan; RHMS: RH with encapsulated Spirulina platensis.

Means followed by the same letter in a column were not significantly different at the $95 \%$ confidence level.

Table 2: Content of crude fiber (\% dry basis) and different fractions of soybean straw and ryegrass hay with or without encapsulated Spirulina platensis.

\begin{tabular}{cccc}
\hline Treatment & Crude fiber & NDF & ADF \\
\hline SS & $31.92 \pm 0.62^{\mathrm{c}}$ & $56.66 \pm 0.13^{\mathrm{e}}$ & $46.24 \pm 1.97^{\mathrm{bc}}$ \\
SSG & $29.26 \pm 0.49^{\mathrm{c}}$ & $55.63 \pm 2.05^{\mathrm{ef}}$ & $42.64 \pm 0.89^{\mathrm{cd}}$ \\
SSGS & $29.82 \pm 0.42^{\mathrm{c}}$ & $52.00 \pm 0.88^{\mathrm{f}}$ & $40.13 \pm 0.62^{\mathrm{de}}$ \\
SSF & $43.57 \pm 1.28^{\mathrm{b}}$ & $65.76 \pm 3.16^{\mathrm{cd}}$ & $48.52 \pm 0.18^{\mathrm{bc}}$ \\
SSXC & $52.09 \pm 7.30^{\mathrm{a}}$ & $81.56 \pm 2.32^{\mathrm{a}}$ & $28.49 \pm 0.34^{\mathrm{fg}}$ \\
SSMS & $31.78 \pm 0.98^{\mathrm{c}}$ & $55.61 \pm 0.85^{\mathrm{ef}}$ & $32.23 \pm 2.26^{\mathrm{f}}$ \\
\hline RH & $32.58 \pm 0.34^{\mathrm{c}}$ & $65.88 \pm 0.09^{\mathrm{c}}$ & $40.66 \pm 1.14^{\mathrm{de}}$ \\
RHG & $31.17 \pm 0.32^{\mathrm{c}}$ & $66.51 \pm 0.72^{\mathrm{c}}$ & $40.52 \pm 0.35^{\mathrm{de}}$ \\
RHGS & $29.92 \pm 0.46^{\mathrm{c}}$ & $62.00 \pm 0.19^{\mathrm{d}}$ & $35.16 \pm 2.64^{\mathrm{ef}}$ \\
RHF & $42.81 \pm 0.41^{\mathrm{b}}$ & $84.73 \pm 0.20^{\mathrm{a}}$ & $56.83 \pm 1.34^{\mathrm{a}}$ \\
RHXC & $34.51 \pm 0.31^{\mathrm{c}}$ & $84.02 \pm 0.30^{\mathrm{a}}$ & $52.02 \pm 2.10^{\mathrm{ab}}$ \\
RHMS & $32.90 \pm 0.40^{\mathrm{c}}$ & $72.57 \pm 1.42^{\mathrm{b}}$ & $25.09 \pm 1.78^{\mathrm{g}}$ \\
\hline
\end{tabular}

NDF: neutral detergent fiber; ADF: acid detergent fiber; SS: Soybean straw; SSG: SS with gelatin; SSGS: SSG with Spirulina platensis; SSF: SS fermented by Aspergillus niger; SSXC: SS with xanthan gum and chitosan; SSMP: SS with encapsulated Spirulina platensis; RH: Ryegrass hay; RHG: RH with gelatin; RHGS: RHG with Spirulina platensis; RHF: RH fermented by Aspergillus niger; RHXC: RH with xanthan gum and chitosan; RHMS: RH with encapsulated Spirulina platensis.

Means followed by the same letter in a column were not significantly different at the $95 \%$ confidence level. 


\section{DISCUSSION}

The raw materials (soybean straw and ryegrass hay) showed lower protein levels than those indicated for feeding lactating cows (16-18\%), reiterating the difficulty in using these forages as ruminant feed.

Soybean straw with gelatin and Spirulina showed better results compared to ryegrass hay, with a higher protein and lipid content and lower values of neutral detergent fiber (NDF) and acid detergent fiber (ADF). NDF and ADF are useful measures of feeding value, and is used to evaluate forages and formulate animal feed. NDF is a predictor of voluntary intake because it provides bulk or fill; thus, low NDF values are desired. ADF is a measure of the plant components in forages that are the least digestible by ruminants, including cellulose and lignin.

The decrease in NDF (treatments with gelatin and Spirulina) was due to the absence of cellulose, hemicellulose and lignin in Spirulina cell wall. However, the lower the percentage of NDF, the greater the voluntary consumption by the ruminant, as NDF has a rumen filling effect. This indicates that bulk feed with a higher ADF content contains a greater amount of fibrous components resistant to digestion such as lignin, so the higher the ADF value, the lower the digestibility of the feed [23]. Therefore, ryegrass hay and soybean straw, both with gelatin and Spirulina, showed higher energy value since ADF is an indicator of energy value.

The ryegrass hay had a higher NDF content than soybean straw, and this higher value may be due to the respiration of the plant. After cultivation the plant respiration is only stopped when the water content is less than $35-40 \%$, therefore the slow drying causes loss of soluble carbohydrates which have high digestibility. In this case, a high percentage of cell wall could restrict the attack of digestive enzymes resulting in decreased fiber digestibility and increased retention of solids in the rumen [24].

Nasehi, Entesarian e Pourjamshidian (2019) [25] showed that microalga Spirulina has more crude protein than usual protein meals used for ruminants and its degradability is high in the rumen, which is required. Riad, Elsadany e El-Diahy (2019) [26] conducted a study to evaluate the impact of Spirulina platensis supplementation into the diets of calves. They concluded that the animals fed with diets containing Spirulina presented greater body weight gain.

The fermentation with Aspergillus niger did not show the expected increase for the protein fraction. Although the verified protein content was lower than expected, protein accumulation can be optimized by adding nutrients, such as carbon and nitrogen sources, to the culture media. Glucose, for example, is a simple carbon source, easily assimilated for microbial metabolism in aerobiosis and stimulates the growth of the microorganism. As the protein content is directly proportional to the microbial growth, the use of inducers is justified to increase the protein content. It is important to emphasize the possibility of using solid state fermentation with agro-industrial residues to reduce the costs [6], as well as to increase fiber digestibility for ruminants [7]. There was an increase in the lipid content because fungi also accumulate these components as storage lipids. These lipids can be used as a source of energy and carbon during growth and development [27]. The increase in crude fiber was due to the fact that fungi used primarily the accessible carbohydrates present in the medium [28]. Although solid state fermentation should have enabled the production of enzymes (cellulases, hemicellulases and ligninases) capable of degrading lignocellulose, the results showed that the fungus was unable to produce enough enzymes to degrade digestive-resistant fibrous components, such as lignin.

Fermented soybean straw showed better results than ryegrass hay, with higher protein and lipid content and lower levels of NDF and ADF. However, although the fungal fermentation of soybean straw has improved the quality of the feed, it is necessary to add inductors to increase the protein content.

Free amino acids are degraded in the rumen [29], so adding amino acids to the diet is not necessarily an efficient option to have a greater flow of amino acids in the duodenum [30]. Different strategies can be performed to increase the quality of animal diets, such as the use of coagulants [31]. In recent years there has been an increase in the studies about microencapsulation of organic compounds in order to improve the quality of animal diets [32,33,34], because protein protection is important. The choice of the encapsulating agent is performed according to the $\mathrm{pH}$ of four different ruminants' stomachs. This process aims to preserve the capsule while passing through the 
rumen, reticulum and omasum, finally releasing the core material (Spirulina) in the abomasum ( $\mathrm{pH}$ $<2.1$, obtaining a bypass protein [35].

For both control treatments with empty capsules the increase in crude fiber content indicated a low quality feed. The consumption by the cattle may be reduced due to higher food retention time in the rumen $[36,37]$. The fiber digestion in the rumen's stomach is dependent on the chemical and physical properties of the fiber, and also the rumen's microbial population [38]. The use of empty capsules does not aggregate value to the feed; however, the interaction between chitosan and xanthan gum forms a complex polyelectrolyte by electrostatic attraction, stronger and insoluble in $\mathrm{pH}<6[39,40]$, protecting the microalga Spirulina from ruminal degradation and providing its controlled release.

The addition of encapsulated Spirulina platensis using xanthan gum and chitosan in soybean straw and ryegrass hay increased the protein content, but did not achieve 16\%. The protein content of bulky can be further increased by adding larger quantities of Spirulina once the concentration of encapsulating agents is enough to keep the microalgae trapped. Another option to increase the percentage of protein in the microalgae biomass is through the manipulation of the growing conditions [41]. The addition of encapsulated Spirulina resulted in a decrease in lipid content to soybean straw and ryegrass hay, because the encapsulating agents (xanthan gum and chitosan) were free of fat. The samples with addition of capsules showed higher content of ash, due to the minerals present during the encapsulation process using xanthan gum and chitosan.

Soybean straw with encapsulated Spirulina presented the lowest NDF content. This decrease occurred because the microalga does not contain cellulose, hemicellulose and lignin in its cell wall. The smaller the NDF the higher the voluntary intake by the ruminant, since the NDF has rumen filling effect. According to Siqueira et al. (2012) [42], there may occur differences among forages due to plant cutting lifetime. The newer the plant, the narrower the cell wall, increasing the fiber digestibility. Therefore, according to Silva et al. (2007) [43] NDF lower than 60\% indicates a high quality feed, increasing the feed consumption by the cattle because the fermentation in the rumen is faster.

Comparing the ADF of the biomasses with and without encapsulated Spirulina, the incorporation of the capsules provided higher digestibility, being considered as good quality biomass. According to Soest (1994) [23] the higher the ADF value, the lower the digestibility of the food, this happens because higher ADF biomass contains a higher amount of fibrous components. Components such as lignin are resistant to digestion, which decreases the digestibility. In addition, the ADF is an indicator of energy value. Comparing the two raw materials with addition of encapsulated Spirulina platensis, which had more than $10 \%$ protein, soybean straw presented the most promising results, since the NDF was lower than $60 \%$, being considered a good quality biomass.

Ryegrass is one of the most cultivated grasses in southern Brazil, adapts to low temperatures and grows in different types of soil. Soybean straw is characterized by abundance and low relative cost. However, initially it has low nutritional value with low levels of protein, energy and minerals. Feeding cattle exclusively with soybean straw may result in weight loss for the animal. However, the enrichment of soybean straw and ryegrass hay improved the quality of these raw materials, significantly increasing their nutritional value, being able to be used in the feeding of ruminants and becoming an option for the large volumes of soybean straw and ryegrass hay that are produced and wasted every year due to their lack of use.

\section{CONCLUSION}

The use of soybean straw for cattle feed is an option because there are large volumes that are produced and wasted every year due to its low nutritional value. Ryegrass hay is widely used in the feeding of ruminants, but the low quality due to the cutting and/or drying season, are some of the factors that influence milk productivity and weight gain. The demand for food, for both humans and animals, increases the number of researches looking for alternatives. Spirulina platensis biomass can be produced using wastewater or agro-industrial effluent, and is rich in proteins that cannot be used in formulations intended for human consumption. 
The addition of microalgae biomass in soybean straw and ryegrass hay improved the quality of bulky feed. The addition of Spirulina biomass in soy straw, with gelatin or encapsulated, increased the protein content and decreased the content of NDF and ADF, improving nutritional quality for the feeding of ruminants. The solid state fermentation with the fungus Aspergillus niger did not increase the nutritional properties, being necessary to add nutrients to induce the microorganism to a better accumulation of proteins.

There is a lack of studies related to animal feeding using soybean straw and ryegrass hay enriched with encapsulated Spirulina platensis. The bypass protein obtained using the encapsulated biomass may increase the milk production by lactating cows. In addition, this technology allows the use of agro-industrial waste, adding nutritional value to bulky feed.

\section{ACKNOWLEDGEMENTS}

This study was financed in part by the Coordenação de Aperfeiçoamento de Pessoal de Nível Superior - Brasil (CAPES) - Finance Code 001. The authors are pleased to acknowledge Professor Jorge Alberto Vieira Costa, from Federal University of Rio Grande, Brazil, for supplying Spirulina biomass.

\section{REFERENCES}

1. Mirzaei-Aghsaghali A, Maheri-Sis N. Nutritive value of some agro-industrial by-products for ruminants - A review. World J Zool. 2008;3(2):40-46.

2. Rusinamhodzi L, Corbeels M, Giller KE. Diversity in crop residue management across an intensification gradient in southern Africa: System dynamics and crop productivity. Field Crops Res. 2016;185:79-88, doi: $10.1016 /$ j.fcr.2015.10.007.

3. Cabrera E, Muñoz MJ, Martín R, Caro I, Curbelo C, Díaz, AB. Comparison of industrially viable pretreatments to enhance soybean straw biodegradability. Biores Technol. 2015;194:1-6, doi: 10.1016/j.biortech.2015.06.090.

4. Lee JM, Donaghy DJ, Roche JR. The effect of grazing severity and fertiliser application during winter on herbage regrowth and quality of perennial ryegrass (Lolium perenne L.). Austr J Experim Agric. 2007;47(7):825-832, doi: 10.1071/EA06037.

5. Belay A, Ota Y, Miyakawa K, Shimamatsu H. Current knowledge on potential health benefits of Spirulina. J Appl Phycol. 1993;5(2):235-241, doi: 10.1007/BF00004024.

6. Pandey A. Solid-state fermentation. Biochem Eng J. 2003;13:81-84, doi: 10.1016/S1369703X(02)00121-3.

7. Raimbault M. General and microbiological aspects of solid substrate fermentation. Electr J Biotechnol. 1998;1(3):1-15, doi: 10.2225/vol1-issue3-fulltext-9.

8. Spolaore P, Joannis-Cassan C, Duran E, Isambert A. Commercial applications of microalgae. J Biosci Bioeng. 2006;101(2):87-96, doi: 10.1263/jbb.101.87.

9. Vonshak A, editor. Spirulina platensis (Arthrospira): physiology, cell-biology and biotechnology. Boca Raton (USA): CRC Press; 1997.

10. Dallaire V, Lessard P, Vandenberg G, de la Noüe J. Effect of algal incorporation on growth, survival and carcass composition of rainbow trout (Oncorhynchus mykiss) fry. Biores Technol. 2007;98(7):1433-1439, doi: 10.1016/j.biortech.2006.05.043.

11. Suyama IM, Barison L, Santos SS, Paraíso CM, Stafussa AP, Madrona GS. Aplicação da microalga Spirulina spp. em iogurte liofilizado. Sci Plena. 2020;16(2):021502, doi: 10.14808/sci.plena.2020.021502.

12. Babadzhanov AS, Abdusamatova N, Yusupova FM, Faizullaeva N, Mezhlumyan LG, Malikova MK. Chemical composition of Spirulina platensis cultivated in Uzbekistan. Chem Nat Compounds. 2004;40:276-279, doi: 10.1023/B:CONC.0000039141.98247.e8.

13. Kamalak A, Canbolat O, Gürbüz Y, Özay O. Protected protein and amino acids in ruminant nutrition. J Sci Eng. 2005;8(2):84-88.

14. Pinotti L, Baldi A, Dell'Orto V. Comparative mammalian choline metabolism with emphasis on role in ruminants, especially the high yielding dairy cow. Nutr Res Rev. 2002;15(2):315-331, doi: 10.1079/NRR200247.

15. Gibbs BF, Kermasha S, Alli I, Mulligan C. Encapsulation in the food industry: A review. International J Food Sci Nutr. 1999;50:213-234, doi: 10.1080/096374899101256. 
16. Fang Z, Bhandari B. Encapsulation of polyphenols - A review. Trends Food Sci Technol. 2010;21:510523, doi: 10.1016/j.tifs.2010.08.003.

17. Rodrigues EF, Vendruscolo LP, Bonfante K, Reinehr CO, Colla E, Colla LM. Phycocyanin as substitute for texture ingredients in ice creams. British Food J. 2020;122(2):693-707, doi: 10.1108/BFJ-07-20190553.

18. Rodrigues EF, Ficanha AMM, Dallago RM, Treichel H, Reinehr CO, Machado TP, Nunes GB, Colla LM. Production and purification of amylolytic enzymes for saccharification of microalgal biomass. Biores Technol. 2017;225:134-141, doi: 10.1016/j.biortech.2016.11.047.

19. Argin-Soysal S, Kofinas P, Lo YM. Effect of complexation conditions on xanthan-chitosan polyelectrolyte complex gels. Food Hydrocolloids. 2009;23(1):202-209, doi: 10.1016/j.foodhyd.2007.12.011.

20. AOAC. Official Methods of Analysis of AOAC International. 18. ed. Washington (USA): Association of Official Analytical Chemists; 2005.

21. AOCS. Official and Recommended Practices. 5. ed. Urbana (USA): American Oil Chemists' Society; 2003.

22. Nogueira JMF, Seródio P, Agudo R. Validação de estabilidade de soluções. Bol Soc Portuguesa Quím. 2002;86:51-53

23. Soest PJ. Nutritional Ecology of the Ruminant. 2. ed. New York (USA): Cornell University Press; 1994.

24. Amaral RCD, Trindade JKD, Gentil RS, Souza Júnior SJ. Perdas durante o processo de fenação. MilkPoint [Internet]; 2006 Ago 18 [cited 2015 Jul 7]. Available from: https://www.milkpoint.com.br/artigos/producao/perdas-durante-o-processo-de-fenacao-30618n.aspx

25. Nasehi M, Entesarian M, Pourjamshidian R. Comparison nutritive value of Spirulina platensis algae with some protein meals used in ruminant nutrition. Res Animal Prod. 2019;10(24):27-36, doi: 10.29252/rap.10.24.27.

26. Riad WA, Elsadany AY, El-Diahy YM. Effect of Spirulina platensis microalga additive on performance of growing Friesian calves. J Animal Poultry Prod. 2019;10(2):35-40, doi: 10.21608/JAPPMU.2019.40308.

27. Akpinar-Bayizit A. Fungal lipids: The biochemistry of lipid accumulation. International Journal of Chemical Engineering and Applications 2014;5(5):409-414, doi: 10.7763/IJCEA.2014.V5.419.

28. Tengerdy RP, Szakacs G. Bioconversion of lignocellulose in solid substrate fermentation. Biochem Eng J. 2003;13:169-179, doi: 10.1016/S1369-703X(02)00129-8.

29. Rogers JA, Rishnamoorthy U, Sniffen CJ. Plasma amino acids and milk protein production by cows fed rumen - Protected methionine and lysine. J Dairy Sci. 1987;70(4):789-798, doi: 10.3168/jds.S00220302(87)80075-9.

30. Lapierre H, Pacheco D, Berthiaume R, Ouellet DR, Schwab CG, Dubreuil P, Holtrop G, Lobley GE. What is the true supply of amino acids for a dairy cow? J Dairy Sci. 2006;89:E1-E14, doi: 10.3168/jds.S0022-0302(06)72359-1.

31. Calasans MWM, Furian TQ, Borges KA, Santos LF, Freitas CP, Pilotto F, Santos LR. Evaluation of peroxide index and oxidative rancidity of broiler diets and the occurrence of breast muscle anomalies. Sci Plena. 2020;16(7):070208, doi: 10.14808/sci.plena.2020.070208.

32. Araujo RC, Daley DR, Goodall SR, Jalali S, Guimarães Bisneto OA, Budde AM, Wagner JJ, Engle TE. Effects of a microencapsulated blend of essential oils supplemented alone or in combination with monensin on performance and carcass characteristics of growing and finishing beef steers. Applied Animal Sci. 2019;35:177-184, doi: 10.15232/aas.2018-01822.

33. Kim TB, Lee JS, Cho SY, Lee HG. In vitro and in vivo studies of rumen-protected microencapsulated supplement comprising linseed oil, vitamin e, rosemary extract, and hydrogenated palm oil on rumen fermentation, physiological profile, milk yield, and milk composition in dairy cows. Animals. 2020;10:1631, doi: 10.3390/ani10091631.

34. Swaggerty CL, Arsenault RJ, Johnson C, Piva A, Grilli E. Dietary supplementation with a microencapsulated blend of organic acids and botanicals alters the kinome in the ileum and jejunum of Gallus gallus. PLoS ONE. 2020;15(7):e0236950, doi: 10.1371/journal.pone.0236950.

35. Sarashina T, Ichijo S, Takahashi J, Osame S. Origin of abomasum gas in the cows with displaced abomasum. Nihon Juigaku Zasshi. 1990;52(2):371-378, doi: 10.1292/jvms1939.52.371.

36. Krehbiel CR. Invited review: Applied nutrition of ruminants: Fermentation and digestive physiology. Professional Animal Sci .2014;30(2):129-139, doi: 10.15232/S1080-7446(15)30100-5.

37. Morazán H, Alvarez-Rodriguez J, Seradj AR, Balcells J, Babot D. Trade-offs among growth performance, nutrient digestion and carcass traits when feeding low protein and/or high neutral-detergent fiber diets to growing-finishing pigs. Animal Feed Sci Technol. 2015;207:168-180, doi: 10.1016/j.anifeedsci.2015.06.003. 
38. Huhtanen P, Ahvenjärvi S, Weisbjerg MR, Nørgaard P. Digestion and passage of fibre in ruminants. In: Sejrsen K, Hvelplund T, Nielsen MO, editors. Ruminant physiology: Digestion, metabolism and impact of nutrition on gene expression, immunology and stress. Wageningen (Netherlands): Wageningen Academic Publishers; 2006. p. 87-135.

39. Al-Akayleh F, Al Remawi M, Salemc MS, Badwan A. Using chitosan and xanthan gum mixtures as excipients in controlled release formulations of ambroxol $\mathrm{HCl}$ - in vitro drug release and swelling behavior. J Excipients Food Chem. 2016;5(2):140-148.

40. Dash M, Chiellini F, Ottenbrite RM, Chiellini E. Chitosan - A versatile semi-synthetic polymer in biomedical applications. Progress Polymer Sci. 2011;36(8):981-1014, doi: 10.1016/j.progpolymsci.2011.02.001.

41. Yao C, Pan Y, Lu H, Wu P, Meng Y, Cao X, Xue S. Utilization of recovered nitrogen from hydrothermal carbonization process by Arthrospira platensis. Biores Technol. 2016;212:26-34, doi: 10.1016/j.biortech.2016.03.166.

42. Siqueira GR, Roth MDTP, Moretti MH, Benatti JMB, Resende FDD. Uso da cana-de-açúcar na alimentação de ruminantes. Rev Bra Saúde Prod Animal. 2012;13(4):991-1008, doi: 10.1590/S151999402012000400011.

43. Silva EAD, Berchielli TT, Reis RA, Fernandes JJDR, Sato KJ, Paes JMV. Teores de proteína bruta para bovinos alimentados com feno de tifton 85: consumo e digestibilidades total e parcial. Rev Bras Zoot. 2007;36:237-245, doi: 10.1590/S1516-35982007000100028. 